DOI: https://doi.org/10.32838/2523-4803/70-2-72

УДК 651.4.9:681.3

\title{
Шепель I.B.
}

кандидат економічних наук, доцент, доцент кафедри обліку і оподаткування,

ДВНЗ «Херсонський державний аграрний університет»

\section{Shepel Inesa}

Kherson State Agrarian University

\section{ПЕРЕВАГИ СИСТЕМИ ЕЛЕКТРОННОГО ДОКУМЕНТООБГГУ НА ПІДПРИЕМСТВАХ}

У статті розглянуто організаційні основи визнання статусу електронних документів $і$ впровадження на підприсмстві електронного документообігу. Досліджено основні складники та форми передачі електронного документу від структурних підрозділів та їх виконавців. Згруповано основні етапи організації електронного документообігу, враховуючі особливості ведення облікової політики. Визначено особливості видачі та застосування кваліфікованого електронного підпису (КЕП). Проаналізовано переваги системи електронного документообігу на платформі FossLook. 3апропоновано під час переходу на електронний документообіг розробити власну інструкиію з організації електронного документообігу, враховуючі вимоги чинного законодавства та особливості ведення бізнесу, організувати для відповідальних осіб, які мають знання щодо впровадження електронного документообігу, підвищення кваліфікаиії.

Ключові слова: облік, документ, електронний документ, електронний документообіг, електронний підпис, електронний кабінет.

Постановка проблеми. За допомогою інформаційних технологій компанії намагаються автоматизувати свою роботу за рахунок новітніх електронних технологій. Варто відзначити, що еволюція систем електро- нного документообігу пройшла декілька етапів, починаючи із систем простого обліку документів (існування на папері), продовжуючи системами на електронними копіями паперових оригіналів та дійшовши до систем, 
в яких оригінал документа першочергово має бути електронним, а на папері може існувати копія такого електронного документа.

Європейський досвід та українське законодавство дають змогу ефективно впроваджувати електронний документообіг у приватні структури, використовуючи систему електронного документообігу на різноманітних сучасних платформах.

Аналіз останніх досліджень і публікацій. Даною проблемою займалися А.Н. Сушкевич, Г.В. Нашкерська, Р.М. Косміна, С.А. Кузнецова, О.П. Кундря-Висоцька, Ф.Ф. Бутинець, О.Л. Войналович, І.Л. Томашевська, В.Г. Швець, Н.М. Ткаченко, Л.К. Сук, К. Кручініна, В.М. Рожелюк, П.Н. Денчук, А.О. Ніколашин та ін. Однак, зважаючи на стрімкий розвиток науково-технічного прогресу, комп'ютеризацію облікових процесів, тема впровадження електронного документообігу набуває додаткової актуальності та значимості.

Формулювання цілей статті. Мета статті - визначити переваги системи організації електронного документообігу за допомогою електронних документів та кваліфікованого електронного підпису 3 використанням сучасної інформаційної платформи FossLook.

Виклад основного матеріалу. Первинні та зведені облікові бухгалтерські документи можуть бути складені в паперовій або електронній формі та повинні мати обов’язкові реквізити, установлені п. 2 ст. 9 Закону № 996 «Про бухгалтерській облік та фінансову звітність в Україні» [1]. Зокрема, на думку М.Ю. Карпушенко [2, с. 48-54], документообіг підприємства залежить від таких чинників, як структура підприємства, склад бухгалтерської служби, кількість господарських операцій та порядок їх оформлення, форма організації обліку, тип, вигляд і характер технічних та організаційних засобів, ЕОМ, що використовуються в обліковому процесі.

Первинні документи, складені в електронній формі, застосовуються в бухгалтерському обліку за умови дотримання вимог законодавства про електронні документи та електронний документообіг. Суб'єкти господарювання мають право використовувати у своїй діяльності документи в електронній формі за дотримання норм законів № 851 [3] і № 2155 [4].
Електронний документ - це документ, інформацію в якому зафіксовано у формі електронних даних, включаючи обов’язкові реквізити. Електронний документ може бути створений, переданий, збережений i перетворений електронними засобами на візуальну форму (табл. 1).

Якщо електронний документ надіслано декільком адресатам або зберігається на декількох електронних носіях, то кожний електронний примірник уважається оригіналом такого документу. Контрагенти мають право укладати в електронній формі будь-які види договорів з обов'язковим узгодженням предмета, ціни та строку дії договору [5]. Рекомендуємо передбачити в електронному договорі умову про можливість складання первинної документації також в електронній формі, прописати час і порядок передачі, підписання додаткових змін. У договорі можна передбачити умову про обов'язкове посвідчення електронною печаткою або про відсутність такої вимоги.

Організація документообігу підприємства залежить від масштабу діяльності підприємства, його функцій, кількості ланок управління й обсягу документопотоків. Процеси діловодства та документообігу розглядаються передусім як документальне відображення і забезпечення управлінських процесів. У цьому сенсі діловодство та документообіг слід розглядати як документальне забезпечення управління, тобто як систему вторинних процесів, які забезпечують і відображають процеси управління [6, с. 7].

Електронний документообіг (обіг електронних документів) - сукупність процесів створення, оброблення, відправлення, передавання, одержання, зберігання, використання та знищення електронних документів, які виконуються із застосуванням перевірки цілісності та у разі необхідності з підтвердженням факту одержання таких документів (ст. 10 Закону № 851) [3]. Для впровадження електронного документообігу підприємство повинно самостійно розробити порядок такого документообігу, враховуючи особливості ведення свого бізнесу (структура документообігу, порядок приймання кореспонденції, порядок передачі до структурних підрозділів, перевірка, обробка корес-

Таблиця 1

Основні складники та форми передачі електронного документу

\begin{tabular}{|l|l|}
\hline \multicolumn{1}{|c|}{ Основні складники } & \multicolumn{1}{c}{ Характеристика } \\
\hline Обов’язкові реквізити & $\begin{array}{l}\text { назва документу (форми); } \\
\text { дата складання; назва підприємств, від імені якого складено документ; } \\
\text { зміст, обсяг та одиниця виміру господарської операції; посади осіб, відповідальних за } \\
\text { провадження господарської операції та правильність ї̈ оформлення; } \\
\text { особистий підпис, який дасть змогу ідентифікувати особу, яка взяла участь в оформленні } \\
\text { документа з даної господарської операції }\end{array}$ \\
\hline $\begin{array}{l}\text { Форми передачі електронного } \\
\text { документу }\end{array}$ & $\begin{array}{l}\text { 1. Передача може здійснюватися в електронній формі за допомогою засобів інформаційних } \\
\text { або телекомунікаційних систем. } \\
\text { 2. Шляхом безпосередньої передачі електронного носія (диска, флешки і т. д.), на якому } \\
\text { записано цей документ }\end{array}$ \\
\hline $\begin{array}{l}\text { Кваліфікований електронний } \\
\text { підпис (КЕП) }\end{array}$ & $\begin{array}{l}\text { КЕП прирівнюється до власноручного підпису, це вдосконалений електронний підпис, } \\
\text { який створюється з використанням засобу КЕП і базується на кваліфікованому сертифікаті } \\
\text { і відритого ключа }\end{array}$ \\
\hline
\end{tabular}


понденції, дотримання строків формування та передачі, а також порядок обов'язкового зберігання електронних документів). А.О. Ніколашин наголошує що основні напрями функціонування електронного документообігу залежать від правильного впровадження та використання електронного документообігу, а саме: навчання облікового персоналу, використання потужнішого устаткування та удосконаленого програмного i технічного забезпечення тощо [7].

Головні проблеми переходу компаній на електронний документообіг - звичка працювати 3 документами за звичною схемою та небажання працівників прогресувати. Саме тому в багатьох компаніях усе ще витрачаються дні на узгодження документів, збір підписів, пошук службових записок, листи дублюються, губляться і відсилаються не на ту адресу; процес пошуку потрібного документу займає ще більше часу, ніж період його опрацювання.

Електронний документообіг являє собою процес створення, одержання, оброблення, зберігання, сумісного використання, відправлення, передавання й знищення електронних документів та інформації, яка в них міститься, в рамках певної інформаційної системи [8, с. 34]. Для організації внутрішнього електронного документообігу підприємству достатньо придбати спеціальне програмне забезпечення для генерації електронних підписів. Для врахування особливостей організації електронного документообігу нами сформовано табл. 2.

Згідно 3 наведеною інформацією, підприємства можуть самостійно доповнювати перелік додаткових реквізитів залежно від специфіки своєї діяльності, а також з урахуванням побажань керівника структурного підрозділу, керівників відділів з обов'язковим збереженням комерційної таємниці. Наказом № 1886 [9] затверджено порядок роботи з електронними документами в діловодстві та їх підготовки до передачі в архів на зберігання.

Електронні документи повинні зберігатися на електронних носіях інформації згідно зі строками зберігання відповідних документів на папері. Рекомендуємо продублювати їх на декількох електронних носіях, встановити місце зберігання та відповідальних, тому що дана інформація може містити комерційну таємницю. Отримання КЕП регламентується Законом № 2155 [4], в якому передбачено три види електронного підпису (ст. 1):

- електронний підпис (ЕП);

- удосконалений електронний підпис (УЕП), створений у результаті криптографічного перетворення електронних даних, з якими пов'язаний цей ЕП;

- кваліфікований електронний підпис (КЕП), тільки КЕП прирівнюється до власноручного підпису.

Нами в табл. 3 згруповано особливості видачі та документообігу КЕП.

Згідно 3 п. 4.6 Положення № 88 [10], помилки в первинних електронних документах виправляються відповідно до законодавства. Рекомендуємо процедуру виправлення помилок за зовнішнього документообігу узгодити з адресатом та встановити порядок виправлення помилок в електронних документах:

- або скасувати документ із помилкою та оформити новий;

- або вносити зміни до вже створеного документу 3 обов'язковим збереженням історії зміни.

Власник КЕП не має права передавати його третім особам. Зараз до 07.11.2020 затверджено строк заміни ЕЦП на КЕП. Видача КЕП відноситься до електронних довірчих послуг (далі - надавачі), перелік яких міститься у Довірчому списку (ст. 30 Закону № 2155). Такий список можна знайти на сайті засвідчувального Центрального органу Міністерства юстиції (https://czo. gov.ua). Окрім видачі КЕП, надавачі надають послуги 3 видачі електронної печатки, формування, перевірки та підтвердження електронної оцінки часу, реєстрації електронної доставки і т. д.

Для отримання КЕП фізичною особою або фізичною особою - підприємцем в АЦСК ІДД ДФС слід подати реєстраційну картку, копію паспорта підписанта та копію картки платника податків. Для праців-

Таблиця 2

Етапи організації електронного документообігу та їх характеристика

\begin{tabular}{|c|c|}
\hline Основні складники & Характеристика \\
\hline $\begin{array}{l}\text { Додаткові реквізити для } \\
\text { організації електронного } \\
\text { документообігу }\end{array}$ & $\begin{array}{l}\text { відмітка про користування документом із зазначенням посадової особи, яка відкрила } \\
\text { документ, дата і час; } \\
\text { відмітка про зміну документа із зазначенням даних співробітника, дати та часу, а також } \\
\text { інформації про те, що саме було змінено в документі (чим зумовлено); } \\
\text { посилання на супровідні документи }\end{array}$ \\
\hline $\begin{array}{l}\text { Порядок зберігання електронних } \\
\text { документів }\end{array}$ & $\begin{array}{l}\text { встановлені загальні вимоги нормативними документами. Слід ураховувати, що } \\
\text { документи постійного і тривалого (понад } 10 \text { років) підприємства зобов'язані зберігати у } \\
\text { двох формах: паперовій та електронній }\end{array}$ \\
\hline $\begin{array}{l}\text { Умови зберігання електронних } \\
\text { документів }\end{array}$ & $\begin{array}{l}\text { інформація повинна бути доступною для подальшого використання; } \\
\text { повинна бути забезпечена можливість відновлення електронного документу в тому } \\
\text { форматі, в якому він був створений; } \\
\text { необхідно зберігати інформацію, яка дає змогу встановити походження, призначення, } \\
\text { дату відправлення, отримання, строки виконання }\end{array}$ \\
\hline $\begin{array}{l}\text { Виправлення помилок в } \\
\text { електронних документах }\end{array}$ & $\begin{array}{l}\text { підприємство самостійне встановлює порядок виправлення помилок в електронних } \\
\text { документах (окрім електронної звітності до контролюючих органів) }\end{array}$ \\
\hline
\end{tabular}


Особливості видання та застосування кваліфікованого електронного підпису (КЕП)

\begin{tabular}{|l|l|}
\hline \multicolumn{1}{|c|}{ Особливості } & \multicolumn{1}{c|}{ Характеристика } \\
\hline Видача КЕП & $\begin{array}{l}\text { АЦСК інформаційно-довідкового департаменту ДФС (АЦСК ІДД ДФС) } \\
\text { АЦСК органів юстиції; } \\
\text { Держпідприємство «Національні інформаційні системи» і т. д. }\end{array}$ \\
\hline $\begin{array}{l}\text { Документи для } \\
\text { отримання КЕП }\end{array}$ & $\begin{array}{l}\text { Укладання договору про надання кваліфікованих електронних довірчих послуг. Перелік документів } \\
\text { надається на офіційних сайтах відповідного АЦСК, який вибирає підприємство }\end{array}$ \\
\hline Строк діє КЕП & $\begin{array}{l}\text { Законодавчими документами не передбачено, але КЕП, виданий АЦСК ІДД ДФС, становить два } \\
\text { роки. Після закінчення строку дії КЕП потрібно звернутися до надавача }\end{array}$ \\
\hline Вартість КЕП & Розмір плати розміщується на сайтах. КЕП, виданий АЦСК ІДД ДФС, оформлюється безкоштовно \\
\hline Носії видачі КЕП & $\begin{array}{l}\text { Флеш-носії або оптичний носій СD/DVD; } \\
\text { захищений носій особистих ключів «Алмаз-1К), «Кристал - 1»; } \\
\text { сім-картка особи - у разі отримання послуги Мовіlе ID 9дану послуги надають оператори мобільного } \\
\text { зв'язку «Київстар», «Водафон» }\end{array}$ \\
\hline
\end{tabular}

ників юридичних осіб (директора, головного бухгалтера і т. д.) треба подати реєстраційну картку, додаток до реєстраційної картки (два примірника), оригінал статуту або нотаріально завірену копію (тільки для ознайомлення), копію картки платника податків, наказ про призначення на посаду, копії паспорта заявника.

Згідно $з$ п. 1 ст. Закону № 2155, сертифікат скасовується не пізніше ніж протягом 2 двох годин суб' єктом, який його видав, у разі:

1) подання користувачем заяви про скасування виданого йому сертифікату;

2) надходження до суб'єкта, який видав сертифікат, документа, який підтверджує (смерть фізичної особи підписанта, зміни в ідентифікаційних даних, факт державної реєстрації припинення підприємницької діяльності, факт компрометації особистого ключа або набуття законної сили рішення суду про скасування сертифіката).

Слід зауважити, що загублений сертифікат не підлягає відновленню у разі втрати, пошкодження особистого ключа або втрати пароля до нього. Тому власнику КЕП необхідно звернутися особисто до надавача, який видав сертифікат, та написати заяву про зміну статусу сертифіката та новий комплект документів. При цьому повторне оформлення сертифіката не подовжує строк його дії.

На практиці застосовують два методи обліку КЕП. Затрати на придбання КЕП відображаються як:

- поточні адміністративні витрати: Дт 92 «Адміністративні витрати» - Кт 685 «Розрахунки з іншими кредиторами»;

- витрати майбутніх періодів (оскільки КЕП використовується протягом декількох звітних періодів): Дт 39 «Витрати майбутніх періодів», а потім поступово списуються в дебет рахунку 92.

За отримання безоплатно КЕП у платників податків не виникають витрати і немає доходу, який можна достовірно оцінити (п. 5 П(С)БО 15 «Дохід»). Якщо КЕП було придбано у платника ПДВ, підприємство має право на податковий кредит за наявності зареєстрованої в СРПН податкової накладної. Під час придбання КЕП у платника податку на прибуток виникає нематеріальний актив групи 6 - інші нематеріальні активи (право на ведення діяльності, використання економіч- них та інших привілеїв). Строк дії права користування цими активами нормами ПКУ не встановлений, і підприємства можуть самостійно визначити строк корисного використання (від 2 до 10 років). На підприємствах, які не повинні коригувати фінансовий результат на податкові різниці, ведення податкового обліку не викличе проблем під час перевірки. А підприємствам, які зобов'язані коригувати фінансовий результат, потрібно враховувати роз'яснення ДФС або отримати індивідуальну податкову консультацію.

Починаючи 31999 р. компанія «ФОСС-Он-Лайн» працює на ринку інформаційних технологій, спеціалізується на розробленні, впровадженні і супроводі програмного забезпечення в таких сферах: корпоративна електронна пошта, розподілений обмін даними, системи електронного документообігу, бібліотеки інтерфейсу користувача.

Система електронного документообігу - це FossDoc-рішення на платформі FossLook, призначене для створення електронного архіву документів, організації корпоративного документообігу (workflow) і автоматизації бізнес-процесів на підприємствах, в установах і організаціях будь-якого роду діяльності. Програма дає змогу вирішити велику кількість завдань, реалізація яких покладена на відповідні модулі. Система може бути легко перелаштована 3 урахуванням специфіки роботи кожного конкретного підприємства [11].

Дана система знайшла широке застосування в банківській системі України, а також у багатьох державних i комерційних організаціях. Серед найбільших замовників - Національний банк України, «Ощадний Банк», «Промінвестбанк», «Укрсиббанк», «Райффайзен Банк Аваль», «Укрсоцбанк», а також Харківська, Закарпатська, Сумська і Чернігівська обласні державні адміністрації, Державне казначейство України, Пенсійний фонд України, Державна податкова адміністрація України і багато інших організацій та установ. «ФОСС-Он-Лайн» бере участь у партнерській програмі Microsoft у статусі Microsoft Gold Certified Partner («Золотий партнер»). «Золоті партнери» є партнерами Microsoft вищого рівня і мають доступ до інструментів і підтримки, необхідних для збереження міцних позицій на ринку. 
Висновки. Під час переходу на електронний документообіг потрібно розробити власну інструкцію 3 організації електронного документообігу, враховуючі вимоги чинного законодавства й особливості ведення бізнесу, та призначити відповідальних осіб, які мають знання щодо впровадження електронного документообігу. За необхідності доцільним є залучення спеціалістів зі сторонньої організації. Із набуттям чинності Закону № 21555 поняття «ЕЦП» було замінено поняттям «КЕП». При цьому ЕЦП будуть діяти до 07.11.2020. Суб'єкти підприємницької діяльності та фізичні особи можуть отримати КЕП лише у кваліфікованих надавачів електронних довірчих послуг.
Перелік документів регламентує кожний АЦСК ознайомитися 3 ним можна на офіційних сайтах АЦСК. У бухгалтерському обліку затрати на придбання КЕП відображаються у складі адміністративних витрат або як витрати майбутніх періодів.

Система електронного документообігу FossDoc знайшла широке застосування в банківській системі України, а також у багатьох державних і комерційних організаціях. Витрати на ведення електронного документообігу окупаються не лише завдяки підвищенню швидкості обміну інформацією та скороченню витрат на зберігання паперів, а й зменшенню кількості працівників, зайнятих роботою $з$ документами.

\section{Список літератури:}

1. Про бухгалтерській облік та фінансову звітність в Україні : Закон України від 16.07.1999 № 996-XIV / Верховна Рада України. URL : https://zakon.rada.gov.ua/laws/show/996-14 (дата звернення: 18.03.2020).

2. Карпушенко М.Ю. Організація обліку : навчальний посібник. Харків : ХНАМГ, 2011. 241 с.

3. Про електронні документи та електронний документообіг : Закон України від 22.05.2003 № 851-IV / Верховна Рада України. URL : https://zakon.rada.gov.ua/laws/show/851-15 (дата звернення: 18.03.2020).

4. Про електронні довірчі послуги : Закон України від 05.10.2017 № 2155-VIII / Верховна Рада України. URL : https://zakon.rada.gov.ua/laws/show/2155-19 (дата звернення: 18.03.2020).

5. Організація електронного документообігу на підприємстві. URL : https://balance.ua/news/post/organizaciyaelektronnogo-dokumentooborota-na-predpriyatii (дата звернення: 18.03.2020).

6. Матвієнко О.В., Цивін М.Н. Основи організації електронного документообігу : навчальний посібник. Київ : Центр учбової літератури, 2008. 112 с.

7. Ніколашин А.О. Проблеми електронного документообігу та шляхи їх вирішення. Облік і фінанси АПК : бухгалтерський портал. 2020. URL : http://magazine.faaf.org.ua/problemi-elektronnogo-dokumentoobigu-ta-shlyahi-ihvirishennya.html (дата звернення: 18.03.2020).

8. Крутова А.С. Електронний документообіг на підприємствах електронної комерції. Економіст. 2011. № 3. C. $31-35$.

9. Про затвердження Порядку роботи з електронними документами у діловодстві та їх підготовки до передавання на архівне зберігання : Наказ Міністерства юстиції України від 11 листопада 2014 р. № 1886/5. URL : http://search.ligazakon.ua/__doc2.nsf/link1/RE26198Z.html (дата звернення: 18.03.2020).

10. Положення про документальне забезпечення записів у бухгалтерському обліку : Наказ Міністерства фінансів України від 24 травня 1995 p. № 88. URL : https://zakon.rada.gov.ua/laws/show/z0168-95 (дата звернення: 17.03.2020).

11. Система електронного документообігу. URL : https://fossdoc.com/about (дата звернення: 19.03.2020).

\section{References:}

1. Pro bukhhalterskyi oblik ta finansovu zvitnist v Ukraini : Zakon Ukrainy vid 16 lypnia 1999 r. № 996-XIV [On Accounting and Financial Reporting in Ukraine : Law of Ukraine of July 16, 1999 No. 996-XIV] The Verkhovna Rada of Ukraine. Available at: http://zakon.rada.gov.ua/laws/show/996-14 (accessed 18 March 2020).

2. Karpushenko M.Yu. (2011) Orhanizatsiia obliku : navchalnyi posibnyk [Accounting organization: a textbook] Kh.: KhNAMH, 2011. p. 241. (in Ukrainian)

3. Pro elektronni dokumenty ta elektronnyi dokumentoobih : Zakon Ukrainy vid 22 travnia 2003 r. № 851-IV [On electronic documents and electronic document : Law of Ukraine of May 22, 2003 No. 851-IV] The Verkhovna Rada of Ukraine. Available at: https://zakon1.rada.gov.ua/laws/show/851-15 14 (accessed 18 March 2020).

4. Pro elektronni dovirchi posluhy : Zakon Ukrainy vid 05 zhovtnia 2017 r. № 2155-VIII [On electronic trust services : Law of Ukraine of October 05, 2017 No. 2155-VIII] The Verkhovna Rada of Ukraine. Available at: https://zakon.rada.gov.ua/ laws/show/2155-19 (accessed 18 March 2020).

5. Orhanizatsiia elektronnoho dokumentoobihu na pidpryiemstvi [Organization of electronic document flow at the enterprise]. Available at: https://balance.ua/news/post/organizaciya-elektronnogo-dokumentooborota-na-predpriyatii (accessed 18 March 2020).

6. Matviienko O. V., Tsyvin M. N. (2008) Osnovy orhanizatsii elektronnoho dokumentoobihu: navchalnyi posibnyk [Fundamentals of Electronic Document Management ]. Kyiv: Center for Educational Studies, p. 112. (in Ukrainian)

7. Nikolashyn A.O. (2020) Problemy elektronnoho dokumentoobihu ta shliakhy yikh vyrishennia. Oblik i finansy APK: bukhhalterskyi portal [Problems of electronic workflow and ways of solving them. Accounting \& Finance AIC: Accounting Portal]. Available at: http://magazine.faaf.org.ua/problemi-elektronnogo-dokumentoobigu-ta-shlyahi-ih-virishennya.html (accessed 18 March 2020). 
8. Krutova A. S. (2011) Elektronnyi dokumentoobih na pidpryiemstvakh elektronnoi komertsii. Ekonomist [Electronic workflow at e-commerce enterprises. Economist]. vol. 3. pp. 31-35. (in Ukrainian)

9. Polozhennia pro dokumentalne zabezpechennia zapysiv u bukhhalterskomu obliku: Ministerstva finansiv Ukrainy vid 11 lystopada 2014 r. № 1886/5. [On Approval of the Procedure for Working with Electronic Documents in Records and Preparing them for Transfer to Archival Storage: Order of the Ministry of Justice of Ukraine of November 11, 2014 No. 1886/5]. Available at: https://zakon.rada.gov.ua/laws/show/z0168-95 (accessed 18 March 2020).

10. Polozhennia pro dokumentalne zabezpechennia zapysiv u bukhhalterskomu obliku : Nakaz Ministerstva finansiv Ukrainy vid 24 travnia 1995 r. № 88 [Provisions for documentary support of accounting records : Order of the Ministry of Finance of Ukraine of May 24, 1995 No. 88]. Available at: https://zakon.rada.gov.ua/laws/show/z0168-95 (accessed 17 March 2020).

11. Systema elektronnoho dokumentoobihu (2020) [Electronic document management system]. Available at: https://fossdoc.com/about (accessed 19 March 2020)..

\section{ПРЕИМУЩЕСТВА СИСТЕМЫ ЭЛЕКТРОННОГО ДОКУМЕНТООБОРОТА НА ПРЕДПРИЯТИЯХ}

В статье рассмотрены организационные основы признания статуса электронных документов и внедрения на предприятии электронного документооборота. Исследованы основные составляющие и формы передачи электронного документа от структурных подразделений и их исполнителей. Сгруппированы основньле этапь организации электронного документооборота, учитывая особенности учетной политики. Определены особенности выдачи и использования квалифицированной электронной подписи. Проанализированы преимущества системы электронного документооборота на платформе FossLook. Предложено при переходе на электронный документооборот разработать собственную инструкиию по организации электронного документооборота, учитывая требования действующего законодательства и особенности ведения бизнеса. Руководителям предприятий рекомендовано организовать повышение квалификации персонала, в обязанности которого будет входить внедрение электронного документооборота.

Ключевые слова: учет, документ, электронный документ, электронный документооборот, электронная подпись, электронньй кабинет.

\section{ADVANTAGES OF THE ELECTRONIC WORKFLOW SYSTEM IN ENTERPRISES}

The use of the electronic workflow over traditional is indisputable, since the main problem of a traditional workflow technology is the practical inability to centrally track the movement of organization's documents. We have identified the main benefits of the electronic workflow: the ability to put in the document multimedia data in addition to text; the possibility of using prearranged forms; high speed of information transmission at a large number of addresses; saving paper; high compactness of the archive; high speed of searching and receiving information; the ability to protect documents from unauthorized access and to distinguish employees' access rights to information. A qualified electronic signature $(Q E S)$ is used to protect documents from counterfeiting. All participants of electronic document exchange receive equal opportunities regardless of their distance from each other. Thus, the idea of electronic workflow already creates good technological preconditions for improving the quality of management and contributes to the formation of a complete electronic workflow system. The company Foss-On-Line operates in the information technology market and specializes in the development, implementation of corporate e-mail, distribution of data exchange, creation of electronic workflow system. The electronic workflow system is FossDoc, i.e., solutions on a FossLook platform, intended for creation of electronic archive of documents, organization of corporate workflow and automation of business processes at enterprises, in institutions and organizations of any kind of activity. The program allows you to solve a large number of tasks, the implementation of which is assigned to the appropriate modules. The system can be easily re-adjusted to the specificities of each company. The electronic workflow system FossDoc has been widely used in the banking system of Ukraine, as well as in many state and commercial organizations, including regional state administrations, the State Treasury of Ukraine, the Pension Fund of Ukraine, the State Tax Administration of Ukraine and many other organizations and institutions. Electronic workflow is easier to optimize. The costs of electronic workflow are paid off not only by increasing the speed of information exchange and reducing the cost of paper storage, but also by reducing the number of employees involved in working with documents.

Key words: accounting, document, electronic document, electronic workflow, electronic signature, electronic cabinet. 